\title{
Risk of death by age and gender from CoVID-19 in Peru, March-May,
} 2020

\author{
Cesar Munayco ${ }^{1,{ }^{*}}$, Gerardo Chowell ${ }^{2,}{ }^{*}$, Amna Tariq ${ }^{2}$, Eduardo A. Undurraga ${ }^{3,4}$, Kenji \\ Mizumoto $2,5,6$
}

${ }^{1}$ Centro Nacional de Epidemiología, Prevención y Control de Enfermedades, Peruvian Ministry of Health, Lima, Peru

${ }^{2}$ Department of Population Health Sciences, School of Public Health, Georgia State University, Atlanta, GA 30303, USA

${ }^{3}$ Escuela de Gobierno, Pontificia Universidad Católica de Chile, Santiago, Region Metropolitana, Chile

${ }^{4}$ Millennium Initiative for Collaborative Research in Bacterial Resistance, MICROB-R, Chile

${ }^{5}$ Graduate School of Advanced Integrated Studies in Human Survivability, Kyoto University Yoshida-Nakaadachicho, Sakyo-ku, Kyoto, Japan

${ }^{6}$ Hakubi Center for Advanced Research, Kyoto University, Yoshidahonmachi, Sakyo-ku, Kyoto, Japan

*Equal contribution

Correspondence to: Kenji Mizumoto; email: mizumoto.kenji.5a@kyoto-u.ac.jp

Keywords: COVID-19, Peru, risk of death, time-delay adjusted CFR, 2020

Received: June 6, $2020 \quad$ Accepted: June 29, $2020 \quad$ Published: July 21, 2020

Copyright: Munayco et al. This is an open-access article distributed under the terms of the Creative Commons Attribution License (CC BY 3.0), which permits unrestricted use, distribution, and reproduction in any medium, provided the original author and source are credited.

\section{ABSTRACT}

Peru implemented strict social distancing measures during the early phase of the epidemic and is now experiencing one of the largest CoVID-19 epidemics in Latin America. Estimates of disease severity are an essential indicator to inform policy decisions about the intensity and duration of interventions needed to mitigate the outbreak. Here we derive delay-adjusted case fatality risks (aCFR) of CoVID-19 in a middle-income country in South America.

We utilize government-reported time series of CoVID-19 cases and deaths in Peru stratified by age group and gender.

As of May 25, 2020, we estimate the aCFR for men and women at 10.8\% (95\%Crl: 10.5-11.1\%) and 6.5\% (95\%Crl: 6.2-6.8\%), respectively, whereas the overall aCFR was estimated at 9.1\% (95\%Crl: $8.9-9.3 \%)$. Our results show that senior individuals have been the most severely affected by CoVID-19, particularly men, with an aCFR of nearly $60 \%$ for those aged 80 - years. We also found that men have a significantly higher cumulative morbidity ratio across most age groups (proportion test, $p$-value $<0.001$ ), with the exception of those aged 0-9 years.

The ongoing COVID-19 pandemic is generating a substantial mortality burden in Peru. Senior individuals, especially those older than 70 years, are being disproportionately affected by the COVID-19 pandemic.

\section{INTRODUCTION}

As of May 25, 2020, more than 5.5 million CoVID-19 cases and about340,000 deaths have been reported from almost every country and territory around the globe $[1,2]$. The ongoing CoVID-19 pandemic has imposed a substantial burden on health systems, economies, and societies globally, and there are strong indicators pointing to a disproportionate impact on low- and middle-income countries [3-5]. Since its initial outbreak in China, the world has tracked the CoVID-19 pandemic proliferating across Europe and Asia, and later seeding hotspots in 
North America, the Middle East, and more recently in Latin America [6]. Brazil reported its first case on February 26, 2020 [7]. Neighboring countries started to report CoVID-19 cases in subsequent days; South America has registered more than 600,000 cases and 30,600 deaths as of May 24, 2020 [1]. Although many South American countries imposed strict control measures, including travel bans, school closures, and lockdowns early in the epidemic, the magnitude of their epidemics now rival those observed in European hotspots, with CoVID-19 cases and death counts increasing rapidly in the region $[1,5]$. Other factors, including high poverty rates, informal economies, frail healthcare systems, insufficient medical supplies as well as inadequate water, sanitation, and hygiene infrastructure further exacerbate the health and socioeconomic impacts of the CoVID-19 pandemic [5, 8-10]. Governments in South America are now facing the social and economic consequences from SARS-COV-2 containment measures, while struggling to contain the rapidly expanding outbreaks of the deadly virus [9].

Peru, a country of about 30 million people, is experiencing one of the largest CoVID-19 epidemics in Latin America. With a rapidly rising case tally, Peru has reported almost 129,148 cases and 7660 deaths as of May 25, 2020 [11]. The majority (63\%) of CoVID-19 cases have been confirmed in Lima, the capital of Peru [11]. The government of Peru initiated social distancing measures soon after the confirmation of the first imported case in Peru on March 6, 2020 [12]. The initial epidemic control measures included school closures on March 11, 2020 followed by the suspension of large gatherings and flights from Europe and Asia the next day. Subsequently the government declared a national emergency and closed its borders on March 16, 2020 [13]. Despite these forthcoming and swift control measures, untraced community transmission was reported by March 17, 2020, forcing the implementation of a night time curfew as of March 18, 2020 [13].

Estimates of the reproduction number from the early stage of the epidemic in Peru (March 2020) showed sustained transmission in Lima with a reproduction number R estimated at 2.3 (95\% CI: 2.0, 2.5) [14]. Moreover, the 20-days ahead forecast for Lima suggested that the prompt social distancing measures had significantly slowed down the initial spread of the virus in the region [14]. Despite the implementation of non-pharmaceutical interventions in Peru, case and death counts have continued to rise rapidly. The crude case fatality risk (CFR), defined as the number of cumulative deaths and cases as of May 25, 2020, in Peru is estimated at $5.9 \%$, which is in good agreement with the global crude CFR average of 6.3\% [15]. Statistical analyses and mathematical models using data from Peru suggest that under current epidemic growth trends, the number of CoVID-19 infected individuals could surpass the country's healthcare system capacity [16].

The clinical spectrum of CoVID-19 ranges from asymptomatic cases to clinical conditions characterized by respiratory failure, to multiorgan and systemic manifestations which can cause death [17-19]. The SARS-CoV-2 virus is more likely to generate severe disease among individuals $\geq 60$ years of age, especially those with preexisting medical conditions that include heart disease, lung disease, diabetes or cancer [20]. Further, CoVID-19 associated deaths occur more frequently (about $80 \%$ of total deaths) in persons aged $\geq 65$ years based on data from the USA, and consistent with data from China indicating that $>80 \%$ CoVID-19 deaths occur among persons aged $\geq 60$ years [21]. Moreover, a higher crude fatality risk has been reported among men (2.8\% for men versus $1.7 \%$ for women) in China [22]. Age adjusted CFR estimates from Peru can be useful to gauge the mortality impact of the pandemic and assess whether the severity patterns are consistent in the South America, a region with fragmented health systems, vast inequality, and high poverty rates.

CFR is a key epidemiological metric that quantifies the severity of an epidemic [23], aiding public health officials assess the type and intensity of interventions that need to be implemented to mitigate its impact [24]. However, it becomes challenging to estimate CFR during an epidemic as CFR estimates are sensitive to right censoring of the data that occurs because of the time lag between the symptoms onset and death [2527]. Moreover, under-reporting of cases because mild or asymptomatic cases can go undetected by disease surveillance systems also overestimates CFR [25, 28], while CFR estimates by subgroup are less prone to sampling bias and help identify the most vulnerable subpopulations. For comparison, the infection fatality risk (IFR) is calculated by the ratio of cumulative deaths over the cumulative number of infected individuals.

Given the importance of timely CFR estimates for public health decision making, we provide real-time estimates of adjusted age-specific CFR during the CoVID-19 epidemic in Peru, through May 25, 2020 to assess the pandemic's severity variation in this southern hemisphere setting, which helps pinpoint the most vulnerable segments of the population and tailor public health interventions.

\section{RESULTS}

As of May 25, a total of 129,148 cases and 7,660 deaths due to CoVID-19 have been reported by the Ministry of 
Table 1. Distribution of the cases by sex and age groups, as of May 25, 2020.

\begin{tabular}{|c|c|c|c|c|c|c|c|c|}
\hline \multirow[b]{2}{*}{$\begin{array}{l}\text { Age } \\
\text { group }\end{array}$} & \multicolumn{4}{|c|}{ Men } & \multicolumn{4}{|c|}{ Women } \\
\hline & $\begin{array}{c}\text { Cases } \\
(\%)\end{array}$ & $\begin{array}{l}\text { Deaths } \\
(\%)\end{array}$ & $\begin{array}{c}\text { CCFR } \\
(\%)\end{array}$ & $\begin{array}{c}\text { Mortality per } \\
100,000 \text { population }\end{array}$ & $\begin{array}{c}\text { Cases } \\
(\%)\end{array}$ & $\begin{array}{l}\text { Deaths } \\
(\%)\end{array}$ & $\operatorname{cCFR}(\%)$ & $\begin{array}{c}\text { Mortality per 100,000 } \\
\text { population }\end{array}$ \\
\hline All & $\begin{array}{l}78264 \\
(100)\end{array}$ & $\begin{array}{c}5508 \\
(100)\end{array}$ & $7.0 \%$ & 34.0 & $\begin{array}{c}50884 \\
(100)\end{array}$ & $\begin{array}{l}2152 \\
(100)\end{array}$ & 4.2 & 13.1 \\
\hline $0-9$ & $\begin{array}{l}1416 \\
(1.8)\end{array}$ & $\begin{array}{c}10 \\
(0.2)\end{array}$ & 0.7 & 0.4 & $\begin{array}{l}1362 \\
(2.7)\end{array}$ & $\begin{array}{l}11 \\
(0.5)\end{array}$ & 0.8 & 0.4 \\
\hline $10-19$ & $\begin{array}{l}2475 \\
(3.2)\end{array}$ & $\begin{array}{c}8 \\
(0.1)\end{array}$ & 0.3 & 0.3 & $\begin{array}{l}2128 \\
(4.2)\end{array}$ & $\begin{array}{c}6 \\
(0.3)\end{array}$ & 0.3 & 0.2 \\
\hline $20-29$ & $\begin{array}{l}14306 \\
(18.3)\end{array}$ & $\begin{array}{c}32 \\
(0.6)\end{array}$ & 0.2 & 1.2 & $\begin{array}{c}8707 \\
(17.1)\end{array}$ & $\begin{array}{c}19 \\
(0.9)\end{array}$ & 0.2 & 0.7 \\
\hline $30-39$ & $\begin{array}{l}18052 \\
(23.1)\end{array}$ & $\begin{array}{l}169 \\
(3.1)\end{array}$ & 0.9 & 6.6 & $\begin{array}{l}11487 \\
(22.6)\end{array}$ & $\begin{array}{c}49 \\
(2.3)\end{array}$ & 0.4 & 2.0 \\
\hline $40-49$ & $\begin{array}{l}16258 \\
(20.8)\end{array}$ & $\begin{array}{l}499 \\
(9.1)\end{array}$ & 3.1 & 23.7 & $\begin{array}{l}10005 \\
(19.7)\end{array}$ & $\begin{array}{l}140 \\
(6.5)\end{array}$ & 1.4 & 6.7 \\
\hline $50-59$ & $\begin{array}{l}13274 \\
(17.0)\end{array}$ & $\begin{array}{l}1107 \\
(20.1)\end{array}$ & 8.3 & 67.7 & $\begin{array}{c}8124 \\
(16.0)\end{array}$ & $\begin{array}{c}323 \\
(15.0)\end{array}$ & 4.0 & 19.7 \\
\hline $60-69$ & $\begin{array}{l}7034 \\
(9.0)\end{array}$ & $\begin{array}{l}1615 \\
(29.3)\end{array}$ & 23.0 & 150.4 & $\begin{array}{l}5023 \\
(9.9)\end{array}$ & $\begin{array}{c}649 \\
(30.2)\end{array}$ & 12.9 & 56.6 \\
\hline 70-79 & $\begin{array}{l}3620 \\
(4.6)\end{array}$ & $\begin{array}{c}1279 \\
(23.2)\end{array}$ & 35.3 & 207.6 & $\begin{array}{l}2488 \\
(4.9)\end{array}$ & $\begin{array}{c}558 \\
(25.9)\end{array}$ & 22.4 & 85.1 \\
\hline $80-$ & $\begin{array}{l}1769 \\
(2.3)\end{array}$ & $\begin{array}{c}789 \\
(14.3)\end{array}$ & 44.6 & 279.2 & $\begin{array}{l}1536 \\
(3.0)\end{array}$ & $\begin{array}{c}397 \\
(18.4)\end{array}$ & 25.8 & 108.8 \\
\hline
\end{tabular}

Health, Peru. Among men, reported cases were mostly observed among individuals aged 30-39 years $(23.1 \%)$, followed by those aged 40-49 years (20.8\%), and those aged 20-29 years (18.3\%). In contrast, most deaths were reported among those aged 50 years and above, especially among men aged 60-69 (29.3\%) followed by those aged $70-79(23.2 \%)$, aged $50-59$ years $(20.1 \%)$, and aged 80 years and above (14.3\%). (Table 1, Figure 1A, 1B). Data show a similar pattern for women. The majority of reported cases occur in females aged 20-69 years, and the majority of reported deaths occur among women aged 50 years or more. More specifically, most reported cases occur among women aged 30-39 (22.6\%), followed by women aged 40-49 (19.7\%), and 50-59 year olds $(16.0 \%)$. In contrast, most deaths are reported among those aged 60-69 (30.2\%), followed by women aged 7079 (25.9\%), and lastly, women aged 80 years and above (18.4\%). Regarding CoVID-19 mortality per 100,000 population, seniors (individuals $>70$ years of age) were the most affected age group; mortality burden per 100,000 is 279.2 among men aged 80 years and above, and 207.6 among men aged 70-79 years. For women of 80 years of age or more mortality is 108.8 and 85.1 for women aged 70-79 years (Table 1, Figure 1F).

The gender proportions of reported cases by age groups are presented in Figure 1C and Figure 1D. The proportion of cases among men is higher than $50 \%$ across all age groups $\left(\chi^{2}\right.$ test, $\mathrm{p}$-value $\left.<0.001\right)$. Similarly, the proportion of male deaths is also higher than $50 \%$ except for those aged 10-19 years $\left(\chi^{2}\right.$ test, p-value<0.001). Cumulative morbidity ratio by gender and age group is presented in Figure $1 \mathrm{E}$, indicating that cumulative morbidity ratio among men is higher than women across all age groups (proportion test, p-value < 0.001) except for individuals aged $0-9$ years (proportion test, $\mathrm{p}$-value $=0.85$ ). Figure $1 \mathrm{~F}$ illustrates the mortality per 100,000 population directly caused by CoVID-19 by gender and age group. Mortality is higher than among females aged 20 years and above (proportion test, p-value $<0.05$ ), and it is not significantly different among those aged 0-19 years.

Figure 2 shows the cumulative cases and deaths of CoVID-19 by age group for males and females (A through J) over time. The figure suggests cumulative deaths increases after an increase in cumulative cases. The growth curve for overall cumulative cases (all age groups) for men and women appears to increase exponentially until around day 60 (April 29 $9^{\text {th }}, 2020$ ), while exponential growth in cumulative deaths overall (all age groups) for men and women appears to occur until around day 70 (May $9^{\text {th }}, 2020$ ).

Figure 3 illustrates observed and model based posterior estimates of the crude CFR by age group (A-J) and time-delay adjusted CFR by age group (K-T) for men 
and women. Black dots show crude case fatality risks, and light and dark indicate $95 \%$ and $50 \%$ credible intervals $(\mathrm{CrI})$ for posterior estimates, respectively.

Overall, our model based crude CFR fitted the observed data well, except for individuals aged 80 years and above, probably influenced by low reporting rate/ ascertainment bias of cases at an early stage. Crude CFR for most of age groups increased at the early stage of the epidemic, peaked amidst the outbreak day 34 (April $3^{\text {rd }}, 2020$ ) and followed a decreasing trend turning into an almost flat curve.
Overall, our model-based posterior estimates for the time-delay adjusted CFR are substantially higher than the crude observed CFR. These estimates fluctuated at the early stage of the epidemic and then followed a decreasing trend.

The most recent estimates, as of May 25, 2020, of the time-delay adjusted CFR for men and women are $10.8 \%$ (95\% CrI: $10.5-11.1 \%$ ) and 6.5\% (95\% CrI: 6.2-6.8\%), respectively, while overall national estimate is $9.1 \%$ (95\%CrI: 8.9-9.3\%) (Figure 4 and Table 2). Among men, senior citizens appear to be severely affected; the
A

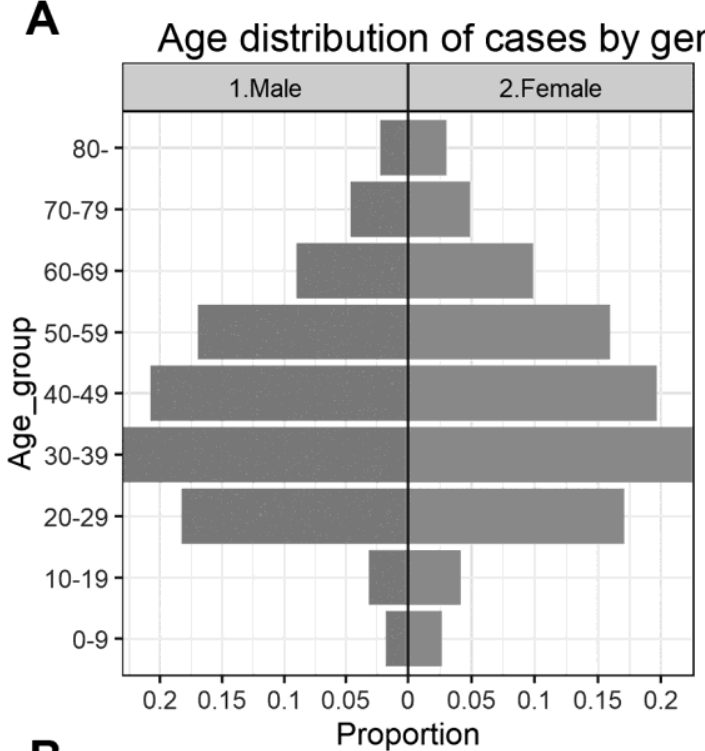

B

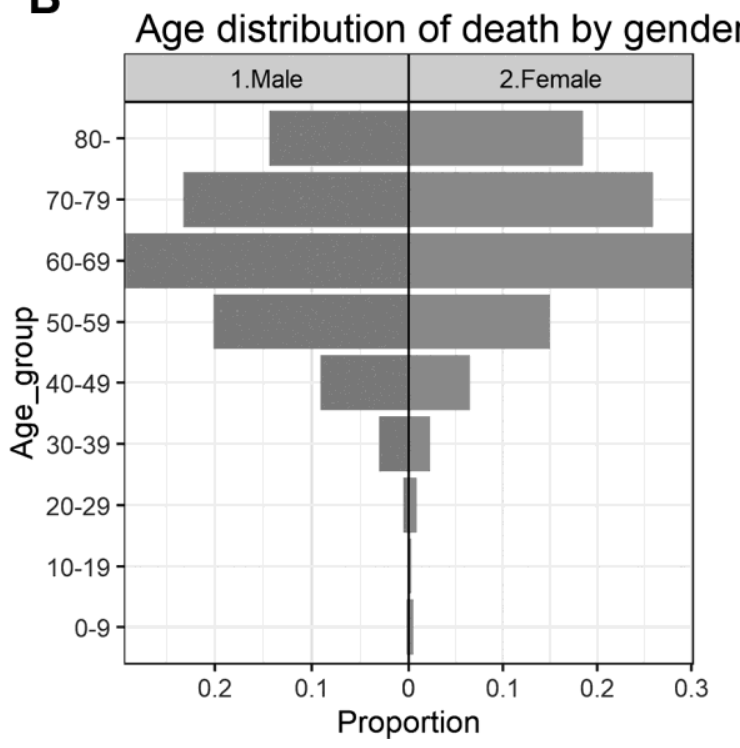

C

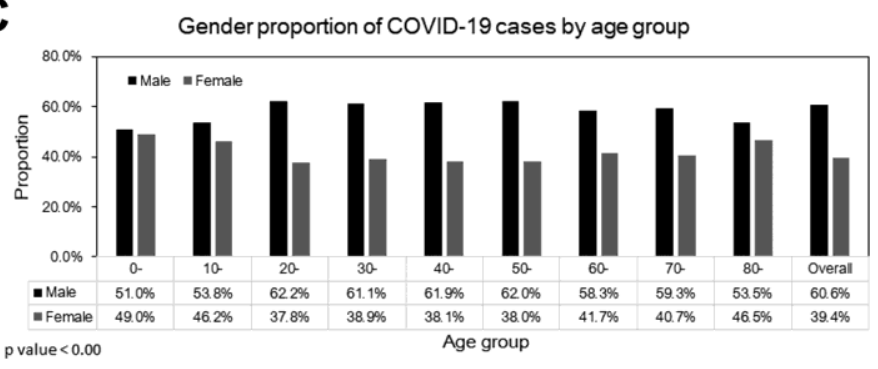

D

Gender proportion of COVID-19 deaths by age group

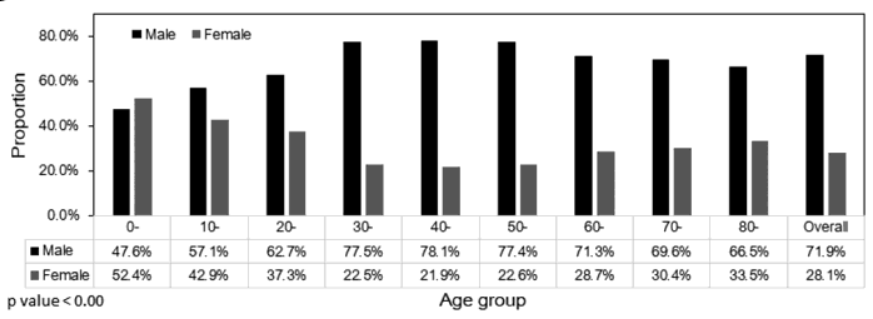

E

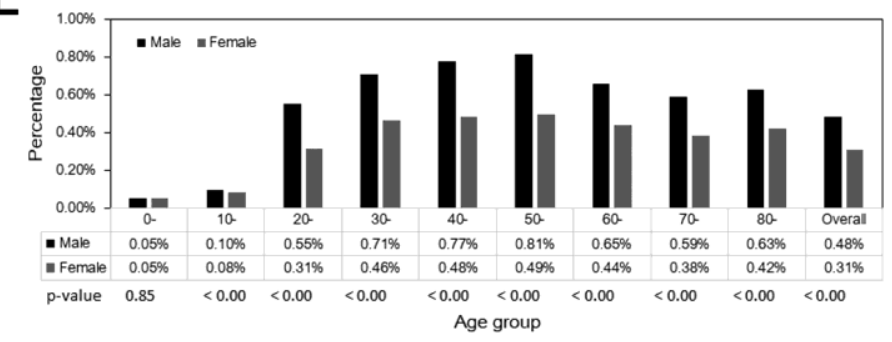

$\mathbf{F}$

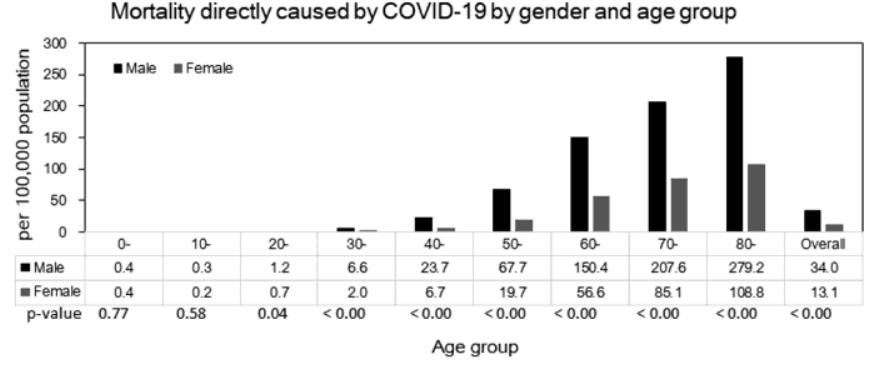

Figure 1. Epidemiological characterization of CoVID-19 in Peru, as of May 25, 2020. (A) Age distribution of reported cases by gender, (B) Age distribution of reported deaths by gender. (C) Gender proportion of CoVID-19 cases by age group, (D) Gender proportion of CoVID-19 deaths by age group, (E) Cumulative morbidity risk by gender and age group, (F) Mortality directly caused by CoVID-19 by gender and age group. 
adjusted CFR is $33.1 \%$ (95\%CrI: $31.7-34.6 \%$ ) for men aged 60-69 years, 49.4\% (95\%CrI: 47.3-51.6\%) for those aged 70-79 years, and $64.3 \%$ (95\% CrI: 60.9$67.8 \%$ ) for those 80 years old and above. We observe a similar pattern for women. The adjusted CFR is $19.2 \%$ (95\% CrI: 17.9-20.6\%) for women aged 60-69 years, $32.2 \%$ (95\%CrI: $29.9-34.7 \%$ ) for those aged $70-79$ years, and $35.1 \%$ (95\%CrI: 32.1-38.1\%) for women aged 80 years old or more.

\section{DISCUSSION}

This study estimates the time-delay adjusted CFR by age group for the ongoing CoVID-19 epidemic in Peru. The crude CFR varies across countries due to differences in testing and timing of tests [29]. The results from our analysis show that the CoVID-19 epidemic in Peru disproportionately impacts senior individuals, especially those who are 70 years of age or older, consistent with CFR estimates obtained from recent studies conducted in China [30, 31], Chile [32], and Italy [33, 34]. This pattern suggests that an aging population could aggravate the fatality impact of CoVID-19, influenza and respiratory syncytial virus [32], as was probably an important factor for its high impact in Italy $[33,34]$. While the population in Lain America, including Peru, is aging at a rapid rate, still a relatively small percentage of the population in the region are older than 65 years of age [35]. Hence, the age structure in the region could favor a lower overall CFR than would be expected otherwise with a relatively older population, as in other regions.

Our estimate of adjusted CFR among men (10.8\% (95\%CrI: $10.5-11.1 \%)$ ) is 1.7 -fold higher than the estimated adjusted CFR for women $(6.5 \%$ (95\% CrI: 6.2$6.8 \%)$ ), consistent with the estimates given in ref [37]. Men aged 80 years or older have an estimated adjusted CFR as high as $64.3 \%$ (95\% CrI: 60.9-67.8\%), 58-fold higher than our estimates for men aged 0-9, and 1.3-fold higher than our estimates for men aged 70-79. Similarly, the adjusted CFR estimates for women of aged 80 years or older are as high as 35.1\% (95\%CrI: 32.1-38.1\%), 29-fold

Male, Cumulative cases
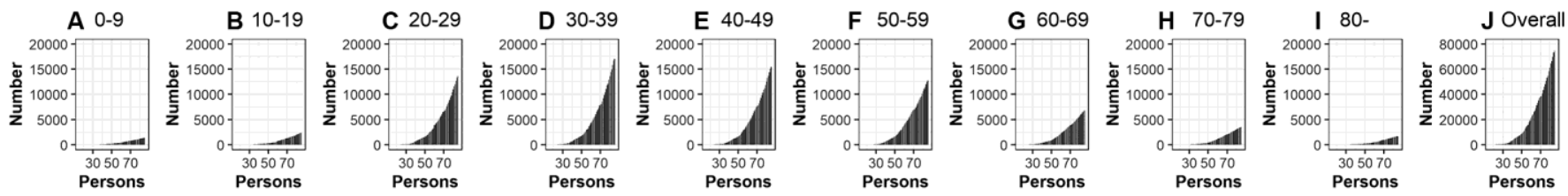

\section{Male, Cumulative deaths}
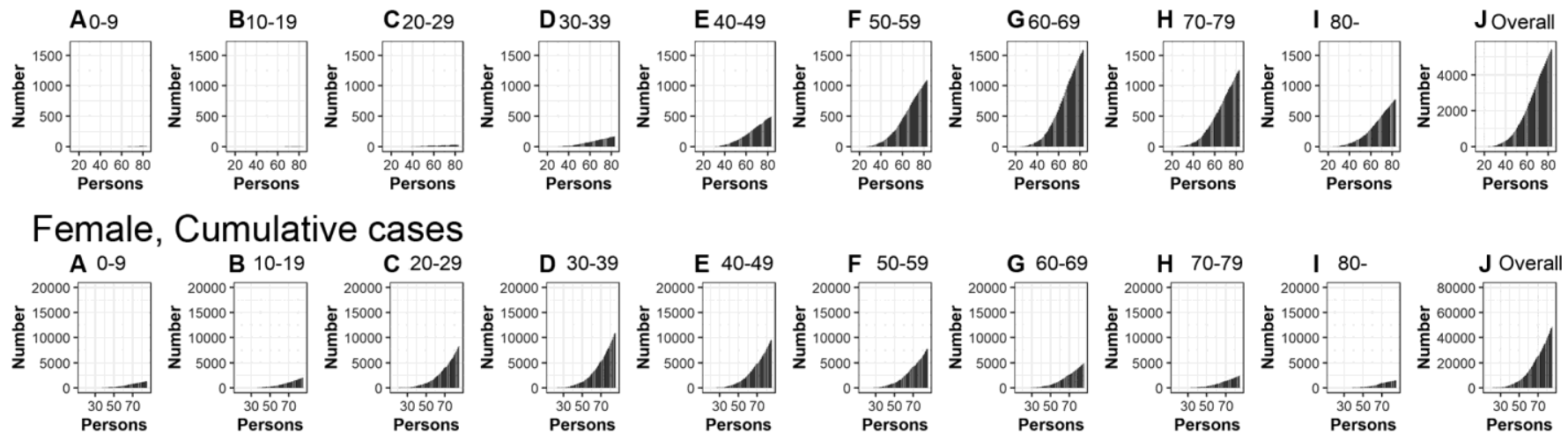

Female, Cumulative deaths
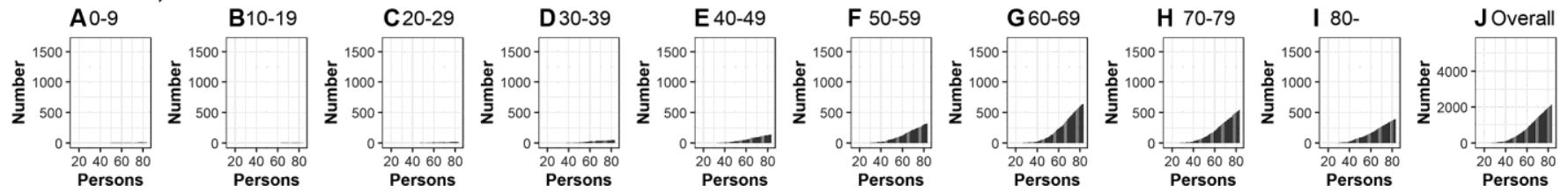

Figure 2. Temporal distribution of cases and deaths by age group due to CoVID-19, March-May 2020, Peru. Top: Male, cumulative cases, Second top: Male, cumulative cases, Second bottom: Female, cumulative cases, Bottom: Female cumulative deaths (A) aged 0-9, (B) aged 10-19, (C) aged 20-29, (D) aged 30-39, (E) aged 40-49, (F) aged 50-59, (G) aged 60-69, (H) aged 70-79, (I) aged 80- and (J) Overall (all age groups). Day 1 corresponds to March 1st in 2020. 
higher than the estimates obtained for female aged 0-9 and 1.1-fold higher than the estimates obtained for female aged 70-79, consistent with recent findings in Chile [32]. In comparison, a study conducted in China, reported much lower estimates of CFR for individuals $>80$ years of age $(13.4 \%)$ [31].

An upward trend in the crude CFR for overall population suggests the disease transmission may be spreading to more vulnerable populations. The majority of social distancing measures in Peru were implemented between March 11-March 18, 2020. However, since $72.4 \%$ of the economically active population works in informal jobs, which are concentrated in the poorest areas of the country, compliance with government mitigation strategies can be challenging despite the government's efforts to support the population [37]. Another factor possibly contributing to the upward trend in crude CFR may be an increase in unreported cases due to saturated testing capacity [29]. However, since Peru's testing capacity has substantially increased since the beginning of the outbreak, going from $>0.01$ test per 1000 population to 0.09 per 1000 in May 22 [15], and the positivity rate estimated at $8.6 \%$ for March, 2020, this seems an unlikely cause. In Peru, about $85 \%$ of ICU beds with ventilators are currently occupied by patients [37], therefore our present estimates are not affected by excess deaths due to health

Male
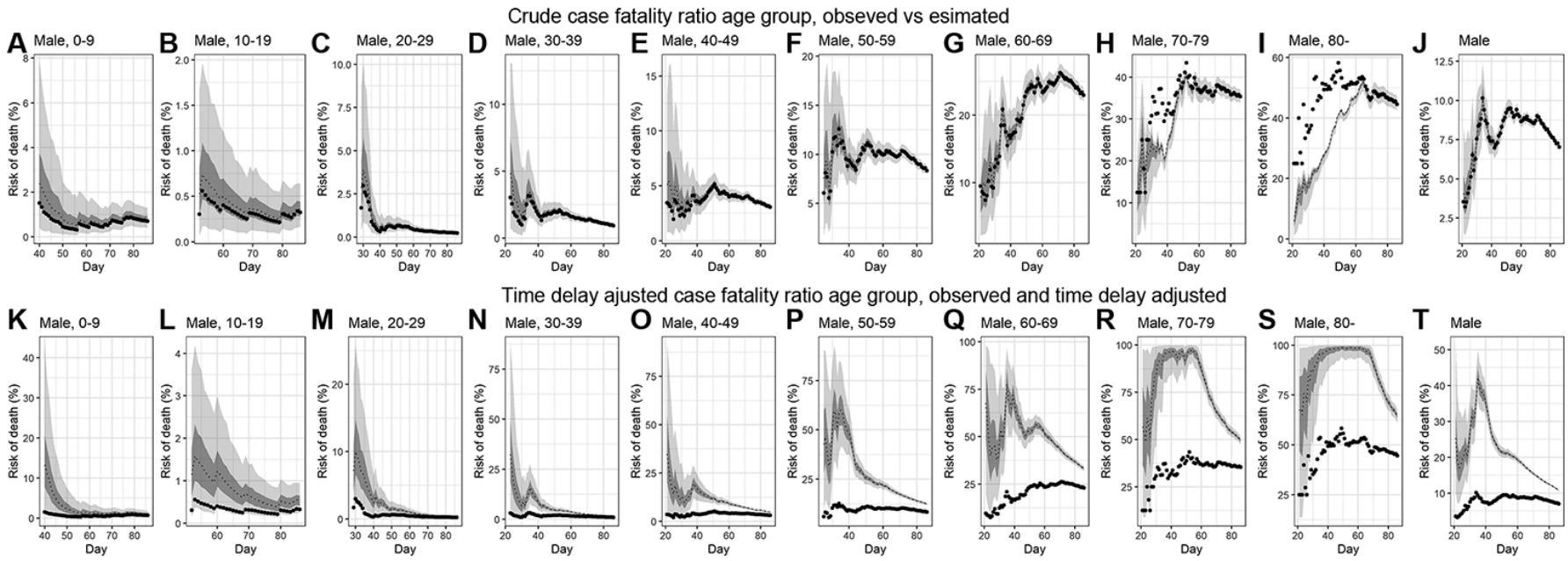

Female
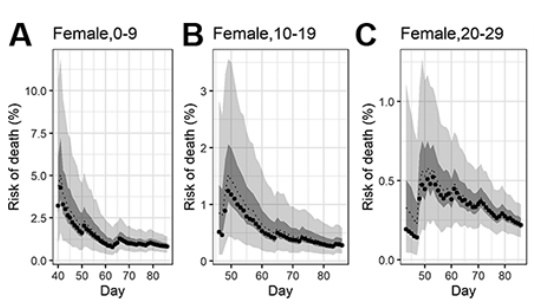

Crude case fatality ratio by age group, obseved vs esimated
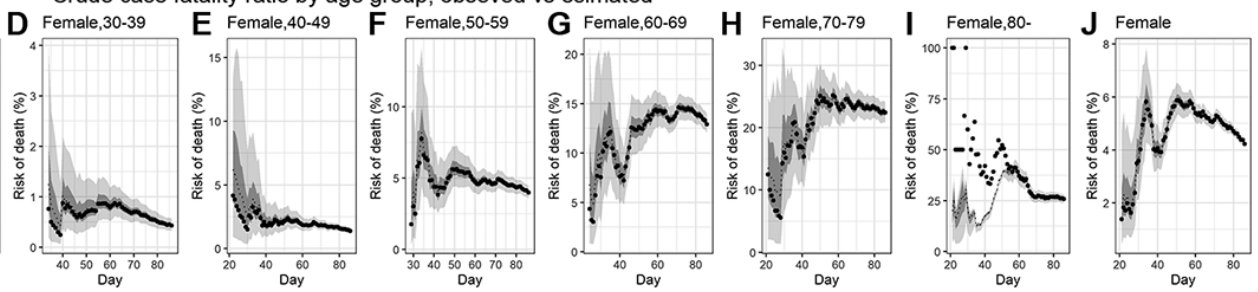

Time delay ajusted case fatality ratio by age group, observed and time delay adjusted
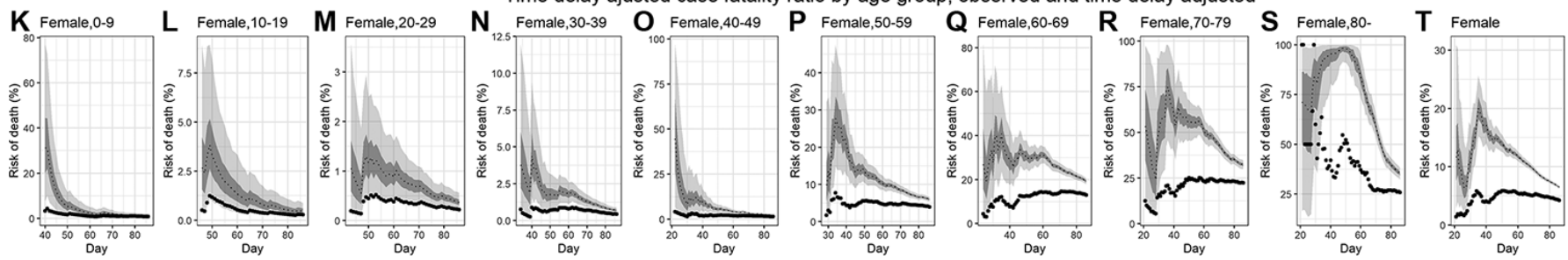

Figure 3. Temporal variation of male and female risk of death by age group caused by CoVID-19, March-May 2020, Peru. Upper two rows; Male risk of deaths, Lower two rows; Female risk of deaths. Observed and posterior estimated of crude case fatality risk of (A) aged 0-9, (B) aged 10-19, (C) aged 20-29, (D) aged 30-39, (E) aged 40-49, (F) aged 50-59, (G) aged 60-69, (H) aged 70-79, (I) aged 80-, (J) all age groups and time-delay adjusted case fatality risk of (K) aged 0-9, (L) aged 10-19, (M) aged 20-29, (N) aged 30-39, (O) aged 40-49, (P) aged 50-59, (Q) aged 60-69, (R) aged 70-79, (S) aged 80-, (T) all age groups. Day 1 corresponds to March 1st in 2020. Black dots show crude case fatality risk, and light and dark indicates $95 \%$ and $50 \%$ credible intervals for posterior estimates, respectively. 
care demand exceeding health care capacity. However, as the epidemic continues to expand, healthcare capacity may be reached in the short term [37]. Furthermore, the results show an increasing trend in crude CFR around day 45 (May $14^{\text {th }}, 2020$ ), probably reflecting the exponential increase of cumulative cases around day 40 (May $9^{\text {th }}, 2020$ ).

The downward trend in the adjusted CFR at the early stage may indicate the existence of a reporting delay and the shift of the outbreak to a less vulnerable segment of the population. In particular, the observed differences in estimates between the crude CFR and adjusted CFR can be attributed to the time-delay that is assumed fixed during the course of the epidemic.

The relatively small proportion of males $(53.5 \%)$ among CoVID-19 cases in the individuals aged 80 years and

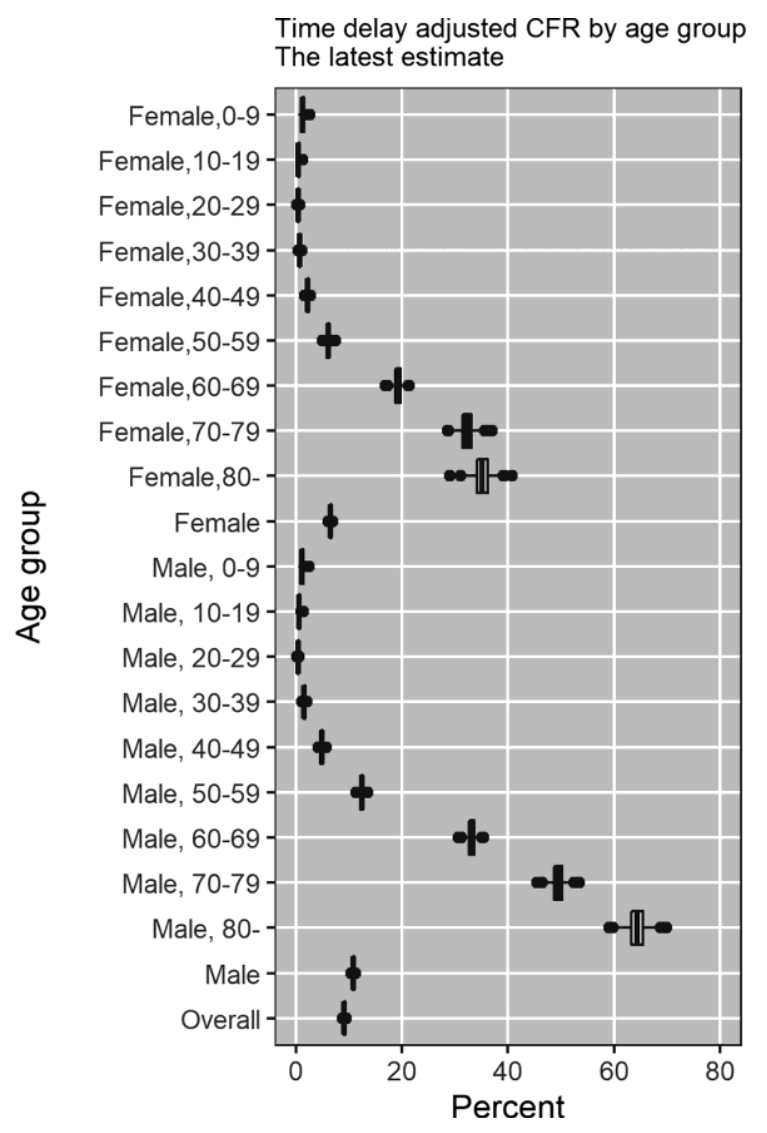

Figure 4. Most recent estimates of time-delay adjusted risk of death caused by CoVID-19 by age group and gender, March-May 2020, Peru. Distribution of time-delay adjusted risk of death from the latest estimates (May 25, 2020) is presented. Top to bottom: female aged 0-9, female aged 10-19, female aged 20-29, female aged 30-39, female aged 40-49, female aged 50-59, female aged 60-69, female aged 70-79, female aged 80 and over, female overall. above can be attributed to the relatively small male population size for that age group; with men comprising only $1.7 \%$ of the population $>80$ years of age in Peru, consistent with estimates for Chile [32]. As higher mortality among male has been reported in China and the U.S. [38], additional data on deaths stratified by gender provides the opportunity to examine the CFR by gender and age.

Several studies documenting the IFR of CoVID-19 have been reported based on an observational study [39], modeling studies [31, 40] and serological studies [41, 42]. While IFR estimates may be more realistic indicators compared to estimates derived from observed cases alone [43, 44], the external validity of these serological studies, e.g., whether the results can be applied to the generalized population in the region where they are performed, needs to be closely examined, as pointed out elsewhere $[40,45,46]$. In particular, to derive IFR estimates, prevalence, the cumulative number of infected people, is estimated based on the result of serological studies. Then, the cumulative number of deaths in the region is divided by the estimated cumulative number of infected individuals.

Indeed, serological studies based on blood donors and outpatients/hospitalized patients will easily lead to overestimation and underestimation, respectively, because the number of infected individuals is expected to be lower among the blood donors and higher among the outpatients/hospitalized patients. In contrast, the death risk derived from the CFR is less affected by the sampling bias and a convenient indicator to identify the vulnerable subpopulations, especially focusing on a single country with relatively uniform testing capacity across the population.

Our study has at least two limitations. First, our estimates are probably overestimated, due to the effect of under reporting rates and ascertainment rates, as has been underscored in other studies [25, 27, 47]. But a recently enhanced testing capacity in Peru is expected to mitigate these effects, and an ongoing mass serological study will provide data to generate more accurate estimates of the death risk. Second, adjusted CFR, especially among seniors, has displayed fluctuations, highlighting the importance of focusing on sub-group analyses. Additional information such as line lists that include related risks including information on underlying diseases may help to identify subgroups with elevated risks.

\section{CONCLUSIONS}

The CoVID-19 pandemic is imposing a large death toll in Peru. Senior individuals, especially those who are 
Table 2. Summary results of time-delay adjusted case fatality risk of CoVID-19 in each age group in Peru, 2020 as of May 25, 2020.

\begin{tabular}{|c|c|c|c|c|}
\hline Age group & Gender & Latest estimate & Range of median estimates & Crude case fatality rate \\
\hline \multirow[t]{2}{*}{ Overall } & & $9.1 \%\left(95 \% \mathrm{CrI}^{\mathrm{a}}: 8.9-9.3 \%\right)$ & $9.1-32.0 \%$ & $5.9 \%\left(95 \% \mathrm{CI}^{\mathrm{b}}: 5.8-6.1 \%\right)$ \\
\hline & & & & $7660 / 129148^{\mathrm{c}}$ \\
\hline \multirow[t]{2}{*}{ Male } & & $10.8 \%$ (95\%CrI: $10.5-11.1 \%)$ & $10.8-42.3 \%$ & $7.0 \%$ (95\%CI: $6.9-7.2 \%)$ \\
\hline & & & & $5508 / 78264$ \\
\hline \multirow[t]{2}{*}{ Female } & & $6.5 \%$ (95\%CrI: $6.2-6.8 \%)$ & $6.4-20.0 \%$ & $4.2 \%$ (95\%CI: $4.1-4.4 \%)$ \\
\hline & & & & $2152 / 50884$ \\
\hline \multirow[t]{4}{*}{$0-9$} & Male & $1.1 \%$ (95\%CrI: $0.5-1.8 \%)$ & $1.0-13.3 \%$ & $0.7 \%$ (95\%CI:0.3-1.3\%) \\
\hline & & & & $10 / 1416$ \\
\hline & Female & $1.2 \%$ (95\%CrI: $0.7-2.0 \%)$ & $1.2-31.4 \%$ & $0.8 \%$ (95\%CI: $0.4-1.4 \%)$ \\
\hline & & & & $11 / 1362$ \\
\hline \multirow[t]{4}{*}{$10-19$} & Male & $0.5 \%$ (95\%CrI: $0.3-1.0 \%)$ & $0.4-1.6 \%$ & $0.3 \%$ (95\%CI: $0.1-0.6 \%)$ \\
\hline & & & & $8 / 2475$ \\
\hline & Female & $0.5 \%$ (95\%CrI: $0.2-0.9 \%)$ & $0.4-3.8 \%$ & $0.3 \%$ (95\%CI: $0.1-0.6 \%)$ \\
\hline & & & & $6 / 2128$ \\
\hline \multirow[t]{4}{*}{$20-29$} & Male & $0.4 \%$ (95\%CrI: $0.2-0.5 \%)$ & $0.4-10.0 \%$ & $0.2 \%$ (95\%CI: $0.2-0.3 \%)$ \\
\hline & & & & $32 / 14306$ \\
\hline & Female & $0.4 \%$ (95\%CrI: $0.2-0.6 \%)$ & $0.4-1.3 \%$ & $0.2 \%$ (95\%CI: $0.1-0.3 \%)$ \\
\hline & & & & $19 / 8707$ \\
\hline \multirow[t]{4}{*}{$30-39$} & Male & $1.5 \%$ (95\%CrI: $1.3-1.7 \%)$ & $1.5-32.3 \%$ & $0.9 \%$ (95\%CI: $0.8-1.1 \%$ ) \\
\hline & & & & $169 / 18052$ \\
\hline & Female & $0.7 \%$ (95\%CrI: $0.5-0.9 \%)$ & $0.9-4.4 \%$ & $0.4 \%$ (95\%CI: $0.3-0.6 \%)$ \\
\hline & & & & $49 / 11487$ \\
\hline \multirow[t]{4}{*}{$40-49$} & Male & $4.8 \%$ (95\%CrI: $4.4-5.2 \%)$ & $4.8-34.7 \%$ & $3.1 \%$ (95\%CI: $2.8-3.3 \%)$ \\
\hline & & & & $499 / 16258$ \\
\hline & Female & $2.2 \%$ (95\%CrI: $1.8-2.5 \%)$ & $2.2-44.6 \%$ & $1.4 \%$ (95\%CI: $1.2-1.6 \%)$ \\
\hline & & & & $140 / 10005$ \\
\hline \multirow[t]{4}{*}{$50-59$} & Male & $12.4 \%$ (95\%CrI: $11.7-13.1 \%)$ & $12.4-60.0 \%$ & $8.3 \%$ (95\%CI: 7.9-8.8\%) \\
\hline & & & & $1107 / 13274$ \\
\hline & Female & $6.0 \%$ (95\%CrI: $5.4-6.7 \%)$ & $7.5-27.7 \%$ & $4.0 \%$ (95\% CI: 3.6-4.4\%) \\
\hline & & & & $323 / 8124$ \\
\hline \multirow[t]{4}{*}{$60-69$} & Male & $33.1 \%$ (95\% CrI: $31.7-34.6 \%)$ & $33.1-77.8 \%$ & $23.0 \%$ (95\%CI: $22.0-24.0 \%)$ \\
\hline & & & & $1615 / 7034$ \\
\hline & Female & $19.2 \%$ (95\% CrI: $17.9-20.6 \%)$ & $19.2-40.9 \%$ & $12.9 \%$ (95\%CI: $12.0-13.9 \%)$ \\
\hline & & & & $649 / 5023$ \\
\hline \multirow[t]{4}{*}{$70-79$} & Male & $49.4 \%$ (95\%CrI: $47.3-51.6 \%)$ & $48.7-97.8 \%$ & $35.3 \%$ (95\%CI: $33.8-36.9 \%)$ \\
\hline & & & & $1279 / 3620$ \\
\hline & Female & $32.2 \%$ (95\%CrI: $29.9-34.7 \%$ ) & $24.1-74.9 \%$ & $22.4 \%$ (95\%CI: $20.8-24.1 \%)$ \\
\hline & & & & $558 / 2488$ \\
\hline \multirow[t]{4}{*}{$80-$} & Male & $64.3 \%$ (95\%CrI: $60.9-67.8 \%)$ & $64.3-98.9 \%$ & $44.6 \%$ (95\%CI: $42.3-47.0 \%)$ \\
\hline & & & & $789 / 1769$ \\
\hline & Female & $35.1 \%$ (95\%CrI: $32.1-38.1 \%)$ & $35.1-98.3 \%$ & $25.8 \%$ (95\%CI: $23.7-28.1 \%)$ \\
\hline & & & & $397 / 1536$ \\
\hline
\end{tabular}

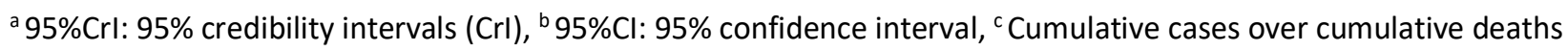


older than 70 years of age, are being disproportionately affected by the CoVID-19 pandemic, particularly elderly men. CFR was as high as $64.3 \%$ (95\% CrI: 60.9$67.8 \%$ ) for men aged 80 older, 58 -fold higher than our estimates for men aged 0-9. The overall adjusted CFR in Peru is estimated to be higher than in other countries, which is worrying, particularly because healthcare demand has not yet exceeded capacity, but probably will do in the coming weeks. The relatively younger age structure in Latin America may help ameliorate the overall CFR than would otherwise be expected with an older age structure in the population.

\section{MATERIALS AND METHODS}

\section{Data}

We obtained daily cumulative numbers of reported laboratory confirmed CoVID-19 cases and deaths stratified by age group and gender through May 25, 2020. Different age groups had different starting times, which correspond to the day when death was reported. Confirmed CoVID-19 cases were retrieved from three surveillance systems: a) national surveillance system (confirmed and suspected cases based on a case definition), b) Netlab system (molecular test) and c) SICOVID system (rapid serological test). CoVID-19 deaths were obtained from two surveillance systems: a) national surveillance system (confirmed and suspected deaths based on a case definition) and b) Vital statistics system (National System of mortality -SINADEF- which is an online system that keeps track of death certificates) [48]. A suspected case presents with acute respiratory infection and with two or more of the following symptoms (cough, sore throat, respiratory distress, nasal congestion or fever), close contact with a CoVID-19 case within 14 days of symptoms onset, or people who live or traveled to cities with community transmission of SARSCoV-2 within 14 days of symptoms onset. On the other hand, the definition of confirmed cases is a suspected case with a positive lab test. [49].

Population size by age, group, and gender in 2020 were retrieved from the Ministry of Health in Peru [50].

\section{Statistical analysis}

The crude CFR is defined as the number of cumulative deaths over the number of cumulative cases. For the estimation of CFR in real time, we employed the delay from hospitalization to death, $\mathrm{h}_{s}$, which is assumed to be given by $\mathrm{h}_{s}=\mathrm{H}(\mathrm{s})-\mathrm{H}(\mathrm{s}-1)$ for $\mathrm{s}>0$ where $\mathrm{H}(\mathrm{s})$ is a cumulative density function of the delay from hospitalization to death and follows a gamma distribution with mean 10.1 days and SD 5.4 days, as given in ref, Mizumoto and Chowell [24]. Let $\pi_{a, t i}$ be the time-delay adjusted case fatality risk on reported day $\mathrm{t}_{i}$ in area $a$, the likelihood function of the estimate $\pi_{a, t_{i}}$ is given by equation:

$$
\begin{aligned}
& L\left(\pi_{a, t_{i}} ; c_{a, t}, D_{a, t}\right) \\
& =\prod_{t_{i}}\left(\begin{array}{l}
\sum_{t=1}^{t_{i}} c_{a, t} \\
D_{a, t_{i}}
\end{array}\right)\left(\pi_{a, t_{i}} \frac{\sum_{t=2}^{t_{i}} \sum_{s=1}^{t-1} c_{a, t-s} h_{s}}{\sum_{t=1}^{t_{i}} c_{a, t}}\right)^{D_{a, t_{i}}} \\
& \left(1-\pi_{a, t_{i}} \frac{\sum_{t=2}^{t_{i}} \sum_{s=1}^{t-1} c_{a, t-s} h_{s}}{\sum_{t=1}^{t_{i}} c_{a, t}}\right)^{\sum_{t=1}^{t i} c_{a, t}-D_{a, t_{i}}}
\end{aligned}
$$

where $c_{a, t}$ represents the number of new cases with reported day $\mathrm{t}$ in area $a$, and $D_{a, t_{i}}$ is the cumulative number of deaths until reported day $\mathrm{t}_{i}$ in area $a[51,52]$. Among the cumulative cases with reported day $t$ in area $a, D_{a, t_{i}}$ have died and the remainder have survived the infection. The contribution of those who have died with biased death risk is shown in the middle parenthetical term and the contribution of survivors is presented in the right parenthetical term. We assume that $D_{a, t_{i}}$ is the result of the binomial sampling process with probability $\pi_{a, t_{i}}$.

We used a Monte Carlo Markov Chain (MCMC) method in a Bayesian framework to estimate model parameters. We evaluated the convergence of MCMC chains using the potential scale reduction statistic [53, 54]. Estimates and $95 \%$ credibility intervals for these estimates are based on the posterior probability distribution of each parameter and samples drawn from the posterior distributions. All statistical analyses were conducted in $\mathrm{R}$ version 3.6.1 (R Foundation for Statistical Computing, Vienna, Austria) using the 'rstan' package.

\section{AUTHOR CONTRIBUTIONS}

GC and KM conceived the early study idea. KM implemented statistical analysis. AT and KM wrote the first full draft. CM performed data acquisition. All authors contributed to the revision of the manuscript. AU advised the study, and revised the manuscript. GC advised on and helped shape the research. All authors contributed to the interpretation of the results and edited and commented on several earlier versions of the manuscript. All authors read and approved the final manuscript.

\section{CONFLICTS OF INTEREST}

All authors report no conflicts of interest. 


\section{FUNDING}

This work was supported by the Japan Society for the Promotion of Science (JSPS) KAKENHI [grant Number 20H03940]; the Leading Initiative for Excellent Young Researchers from the Ministry of Education, Culture, Sport, Science and Technology of Japan; Japan Science and Technology Agency (JST) as part of J-RAPID [grant JPMJSC] to [KM]; National Science Foundation RAPID grant \# 2026797 to [GC]; and the ANID Millennium Science Initiative/ Millennium Initiative for Collaborative Research on Bacterial Resistance, MICROB-R, [NCN17_081] to [EU].

\section{REFERENCES}

1. Dong $E$, Du H, Gardner L. An interactive web-based dashboard to track COVID-19 in real time. Lancet Infect Dis. 2020; 20:533-34.

https://doi.org/10.1016/S1473-3099(20)30120-1

PMID:32087114

2. Heymann DL, Shindo N, and WHO Scientific and Technical Advisory Group for Infectious Hazards. COVID-19: what is next for public health? Lancet. 2020; 395:542-45.

https://doi.org/10.1016/S0140-6736(20)30374-3

PMID:32061313

3. World Bank. (2020). The Economy in the Time of CoVID-19. In: Bank W, ed. Semiannual Report of the Latin America and Caribbean Region. (Washington DC: World Bank).

4. Lloyd-Sherlock P, Ebrahim S, Geffen L, McKee M. Bearing the brunt of covid-19: older people in low and middle income countries. BMJ. 2020; 368:m1052. https://doi.org/10.1136/bmj.m1052 PMID:32169830

5. Burki T. COVID-19 in latin america. Lancet Infect Dis. 2020; 20:547-48.

https://doi.org/10.1016/S1473-3099(20)30303-0 PMID:32311323

6. Bedford J, Enria D, Giesecke J, Heymann DL, Ihekweazu C, Kobinger G, Lane HC, Memish Z, Oh MD, Sall AA, Schuchat A, Ungchusak $K$, Wieler $L H$, and WHO Strategic and Technical Advisory Group for Infectious Hazards. COVID-19: towards controlling of a pandemic. Lancet. 2020; 395:1015-18. https://doi.org/10.1016/S0140-6736(20)30673-5 PMID:32197103

7. Rodriguez-Morales AJ, Gallego V, Escalera-Antezana JP, Méndez CA, Zambrano LI, Franco-Paredes C, Suárez JA, Rodriguez-Enciso HD, Balbin-Ramon GJ, Savio-Larriera E, Risquez A, Cimerman S. COVID-19 in latin america: the implications of the first confirmed case in Brazil. Travel Med Infect Dis. 2020; 35:101613. https://doi.org/10.1016/j.tmaid.2020.101613 PMID:32126292

8. The Lancet. COVID-19: learning from experience. Lancet. 2020; 395:1011. https://doi.org/10.1016/S0140-6736(20)30686-3 PMID:32222181

9. Navarro JC, Arrivillaga-Henríquez J, Salazar-Loor J, Rodriguez-Morales AJ. COVID-19 and dengue, coepidemics in Ecuador and other countries in latin america: pushing strained health care systems over the edge. Travel Med Infect Dis. 2020; 101656.

https://doi.org/10.1016/j.tmaid.2020.101656 PMID:32268196

10. Lorenz C, Azevedo TS, Chiaravalloti-Neto F. COVID-19 and dengue fever: a dangerous combination for the health system in Brazil. Travel Med Infect Dis. 2020; 35:101659.

https://doi.org/10.1016/i.tmaid.2020.101659 PMID:32278756

11. MOH. (2020). Sala Situacional COVID-19 Peru.

12. Aquino M and Garrison C. (2020). Peru records first confirmed case of coronavirus, President Vizcarra says. Rueters.

13. Explorer A. (2020). Coronavirus in Peru- the latest updates. (Amazon Explorer).

14. Munayco CV, Tariq A, Rothenberg R, Soto-Cabezas GG, Reyes MF, Valle A, Rojas-Mezarina L, Cabezas C, Loayza M, Chowell G, and Peru COVID-19 working group. Early transmission dynamics of COVID-19 in a southern hemisphere setting: lima-peru: February 29th-March 30th, 2020. Infect Dis Model. 2020; 5:338-45. https://doi.org/10.1016/j.idm.2020.05.001 PMID: 32399507

15. Hasell J, Ortiz-Ospina E, Mathieu E, Ritchie H, Roser M. (2020). To understand the global pandemic, we need global testing - the Our World in Data COVID-19 Testing dataset. Our World in data.

16. Rainisch G, Undurraga EA, Chowell G. A dynamic modeling tool for estimating healthcare demand from the COVID19 epidemic and evaluating population-wide interventions. Int J Infect Dis. 2020; 96:376-83.

https://doi.org/10.1016/i.ijid.2020.05.043 PMID:32425631

17. Cascella M, Rajnik M, Cuomo A, Dulebohn SC, Di Napoli R. Features, Evaluation and Treatment Coronavirus (COVID-19). 2020. In: StatPearls [Internet]. Treasure Island (FL): StatPearls Publishing; 2020.

PMID: $\underline{32150360}$

18. Guan WJ, Ni ZY, Hu Y, Liang WH, Ou CQ, He JX, Liu L, Shan H, Lei CL, Hui DS, Du B, Li LJ, Zeng G, et al, and China Medical Treatment Expert Group for Covid-19. 
Clinical characteristics of coronavirus disease 2019 in China. N Engl J Med. 2020; 382:1708-20.

https://doi.org/10.1056/NEJMoa2002032 PMID: $\underline{32109013}$

19. Wu JT, Leung K, Bushman M, Kishore N, Niehus R, de Salazar PM, Cowling BJ, Lipsitch M, Leung GM. Estimating clinical severity of COVID-19 from the transmission dynamics in Wuhan, China. Nat Med. 2020; 26:506-10.

https://doi.org/10.1038/s41591-020-0822-7 PMID:32284616

20. Stokes EK, Zambrano LD, Anderson KN, Marder EP, Raz KM, El Burai Felix S, Tie Y, Fullerton KE. Coronavirus disease 2019 case surveillance - United States, January 22-May 30, 2020. MMWR Morb Mortal Wkly Rep. 2020; 69:759-65.

https://doi.org/10.15585/mmwr.mm6924e2 PMID:32555134

21. CDC COVID-19 Response Team. Severe outcomes among patients with coronavirus disease 2019 (COVID19) - United States, February 12-March 16, 2020. MMWR Morb Mortal Wkly Rep. 2020; 69:343-46. https://doi.org/10.15585/mmwr.mm6912e2 PMID:32214079

22. Epidemiology Working Group for NCIP Epidemic Response, Chinese Center for Disease Control and Prevention. [The epidemiological characteristics of an outbreak of 2019 novel coronavirus diseases (COVID19) in China]. Zhonghua Liu Xing Bing Xue Za Zhi. 2020; 41:145-151. https://doi.org/10.3760/cma.j.issn.02546450.2020.02.003 PMID:32064853

23. Reed $C$, Biggerstaff $M$, Finelli $L$, Koonin $L M$, Beauvais $D$, Uzicanin A, Plummer A, Bresee J, Redd SC, Jernigan DB. Novel framework for assessing epidemiologic effects of influenza epidemics and pandemics. Emerg Infect Dis. 2013; 19:85-91.

https://doi.org/10.3201/eid1901.120124 PMID:23260039

24. Mizumoto K, Chowell G. Estimating risk for death from coronavirus disease, China, January-February 2020. Emerg Infect Dis. 2020; 26:1251-56. https://doi.org/10.3201/eid2606.200233 PMID:32168464

25. Li R, Pei S, Chen B, Song Y, Zhang T, Yang W, Shaman J. Substantial undocumented infection facilitates the rapid dissemination of novel coronavirus (SARS-CoV-2). Science. 2020; 368:489-93.

https://doi.org/10.1126/science.abb3221 PMID:32179701

26. Jewell NP, Lei X, Ghani AC, Donnelly CA, Leung GM, Ho LM, Cowling BJ, Hedley AJ. Non-parametric estimation of the case fatality ratio with competing risks data: an application to severe acute respiratory syndrome (SARS). Stat Med. 2007; 26:1982-98.

https://doi.org/10.1002/sim.2691

PMID:16981181

27. Lipsitch M, Donnelly CA, Fraser C, Blake IM, Cori A, Dorigatti I, Ferguson NM, Garske T, Mills HL, Riley S, Van Kerkhove MD, Hernán MA. Potential biases in estimating absolute and relative case-fatality risks during outbreaks. PLoS Negl Trop Dis. 2015; 9:e0003846.

https://doi.org/10.1371/journal.pntd.0003846 PMID:26181387

28. Pan A, Liu L, Wang C, Guo H, Hao X, Wang Q, Huang J, He N, Yu H, Lin X, Wei S, Wu T. Association of public health interventions with the epidemiology of the COVID-19 outbreak in Wuhan, China. JAMA. 2020; 323:1-9.

https://doi.org/10.1001/jama.2020.6130 PMID:32275295

29. Asahi K, Undurraga EA, Wagner R. Benchmarking the CoVID-19 pandemic across countries and states in the U.S.A. under heterogeneous testing. medRxiv. 2020. [Epub ahead of print]. https://doi.org/10.1101/2020.05.01.20087882

30. Deng X, Yang J, Wang W, Wang X, Zhou J, Chen Z, Li J, Chen Y, Yan H, Zhang J, Zhang Y, Wang Y, Qiu Q, et al. Case fatality risk of the first pandemic wave of novel coronavirus disease 2019 (COVID-19) in China. Clin Infect Dis. 2020. [Epub ahead of print]. https://doi.org/10.1093/cid/ciaa578 PMID: 32409826

31. Verity R, Okell LC, Dorigatti I, Winskill P, Whittaker C, Imai N, Cuomo-Dannenburg G, Thompson H, Walker PG, Fu $H$, Dighe A, Griffin JT, Baguelin $M$, et al. Estimates of the severity of coronavirus disease 2019: a model-based analysis. Lancet Infect Dis. 2020; 20:669-77.

https://doi.org/10.1016/S1473-3099(20)30243-7 PMID:32240634

32. Undurraga EA, Chowell G, Mizumoto K. Case fatality risk by age from COVID-19 in a high testing setting in Latin America: Chile, March-May, 2020. medRxiv. 2020. [Epub ahead of print]. https://doi.org/10.1101/2020.05.25.20112904

33. Onder G, Rezza G, Brusaferro S. Case-fatality rate and characteristics of patients dying in relation to COVID19 in Italy. JAMA. 2020. [Epub ahead of print]. https://doi.org/10.1001/jama.2020.4683 PMID:32203977

34. Dowd JB, Andriano L, Brazel DM, Rotondi V, Block $P$, Ding $X$, Liu Y, Mills MC. Demographic science aids in understanding the spread and fatality rates of COVID19. Proc Natl Acad Sci USA. 2020; 117:9696-98. 
https://doi.org/10.1073/pnas.2004911117 PMID:32300018

35. Ham-Chande R, Nava-Bolaños I. Convergence Toward Demographic Aging in Latin America and the Caribbean. Annu Rev Sociol. 2019; 45:607-623. https://doi.org/10.1146/annurev-soc-073018-022532

36. Martínez AD. (2020). Peru Passes Coronavirus Risk to the Working Class (disponible en español). (nacla).

37. Castillo M. (2020). Peru seemed to do everything right. So how did it become a Covid-19 hotspot? CNN.

38. Richardson S, Hirsch JS, Narasimhan M, Crawford JM, McGinn T, Davidson KW, Barnaby DP, Becker LB, Chelico JD, Cohen SL, Cookingham J, Coppa K, Diefenbach MA, et al, and the Northwell COVID-19 Research Consortium. Presenting characteristics, comorbidities, and outcomes among 5700 patients hospitalized with COVID-19 in the new york city area. JAMA. 2020; 323:2052-59.

https://doi.org/10.1001/jama.2020.6775

PMID:32320003

39. Russell TW, Hellewell J, Jarvis $\mathrm{Cl}$, van Zandvoort $\mathrm{K}$, Abbott S, Ratnayake R, Cmmid Covid-Working Group, Flasche S, Eggo RM, Edmunds WJ, Kucharski AJ. Estimating the infection and case fatality ratio for coronavirus disease (COVID-19) using age-adjusted data from the outbreak on the diamond princess cruise ship, February 2020. Euro Surveill. 2020; 25:2000256.

https://doi.org/10.2807/1560-

7917.ES.2020.25.12.2000256

PMID:32234121

40. Mizumoto K, Kagaya K, Chowell G. Early epidemiological assessment of the transmission potential and virulence of coronavirus disease 2019 (COVID-19) in Wuhan City: China, January-February, 2020. medRxiv. 2020.

https://doi.org/10.1101/2020.02.12.20022434

41. Ioannidis J. The infection fatality rate of COVID-19 inferred from seroprevalence data. medRxiv. 2020. [Epub ahead of print]. https://doi.org/10.1101/2020.05.13.20101253

42. To KKW, Cheng VCC, Cai JP, Chan KH, Chen LL, Wong $\mathrm{LH}$, et al. Lancet Microbe.

https://doi.org/10.1016/S2666-5247(20)30053-7

43. Wong JY, Wu P, Nishiura H, Goldstein E, Lau EH, Yang L, Chuang SK, Tsang T, Peiris JS, Wu JT, Cowling BJ. Infection fatality risk of the pandemic a(H1N1)2009 virus in hong kong. Am J Epidemiol. 2013; 177:834-40. https://doi.org/10.1093/aje/kws314 PMID:23459950

44. Presanis AM, De Angelis D, Hagy A, Reed C, Riley S, Cooper BS, Finelli L, Biedrzycki P, Lipsitch M, and New
York City Swine Flu Investigation Team. The severity of pandemic H1N1 influenza in the United States, from April to July 2009: a bayesian analysis. PLoS Med. 2009; 6:e1000207.

https://doi.org/10.1371/journal.pmed.1000207

PMID:19997612

45. Wu X, Fu B, Chen L, Feng Y. Serological tests facilitate identification of asymptomatic SARS-CoV-2 infection in Wuhan, China. J Med Virol. 2020; 10:1002.

https://doi.org/10.1002/jmv.25904 PMID:32311142

46. Giugliano F. Mass Coronavirus Antibody Tests Have Serious Limits. Bloomberg Opinion. April 24, 2020.

47. Ghani AC, Donnelly CA, Cox DR, Griffin JT, Fraser C, Lam TH, Ho LM, Chan WS, Anderson RM, Hedley AJ, Leung GM. Methods for estimating the case fatality ratio for a novel, emerging infectious disease. Am J Epidemiol. 2005; 162:479-86. https://doi.org/10.1093/aje/kwi230 PMID:16076827

48. Ministerio de Salud, Peru: Alerta Epidemiológica ante la transmisión de COVID-IS en el Perú.

https://www.dge.gob.pe/portal/docs/alertas/2020/AE 016.pdf.

49. Vargas-Herrera J, Ruiz KP, Nuñez GG, Ohno JM, PérezLu JE, Huarcaya WV, Clapham B, Cortez-Escalante J. [Preliminary results of the strengthening of the national death registry information system]. Rev Peru Med Exp Salud Publica. 2018; 35:505-14.

https://doi.org/10.17843/rpmesp.2018.353.3913 PMID:30517488

50. Instituto Nacional de Estadística e Informáticas. PERÚ: Estimaciones y Proyecciones de Población por Departamento, Sexo y Grupos Quinquenales de Edad 1995-2025. Boletín de Análisis Demográfico No 37. Lima, Setiembre 2009.

https://www.inei.gob.pe/media/principales indicador es/libro 1.pdf

51. Nishiura $H$, Klinkenberg D, Roberts $M$, Heesterbeek JA. Early epidemiological assessment of the virulence of emerging infectious diseases: a case study of an influenza pandemic. PLoS One. 2009; 4:e6852.

https://doi.org/10.1371/journal.pone.0006852 PMID:19718434

52. Tsuzuki S, Lee $H$, Miura F, Chan YH, Jung SM, Akhmetzhanov AR, Nishiura $H$. Dynamics of the pneumonic plague epidemic in Madagascar, August to October 2017. Euro Surveill. 2017; 22:17-00710. https://doi.org/10.2807/1560-7917.ES.2017.22.46.1700710 PMID:29162211

53. Gamerman D, Lopes HF. (2006). Markov chain Monte Carlo: stochastic simulation for Bayesian inference: CRC Press). 
54. Gelman A, Rubin DB. Inference from iterative simulation using multiple sequences. Stat Sci. 1992; 7:457-472.

https://doi.org/10.1214/ss/1177011136 